\title{
The Cactaceae, a family threatened by trade
}

\author{
Sara Oldfield
}

Many people are fascinated by cacti and the trade that has grown up to meet the demand from collectors has depleted many wild populations. Threatened cacti species receive legal protection in some countries, notably the US, but attempts to control international trade through CITES are frustrated by poor enforcement. The author works at the Conservation Unit at the Royal Botanic Gardens, Kew, which is the UK's Scientific Authority for plants under CITES.

The cactus family, credited with over 2000 species, is in trouble in the wild. Throughout its American range from Canada to Patagonia, species are threatened with extinction. Habitat destruction is playing its part, and collecting places an extra burden, particularly on the rarer species.

Within the family a notably high degree of species endemism is found in Mexico. The Threatened Plants Unit of IUCN carried out a survey of the conservation status of Mexican cacti and found that out of over 600 species endemic to the country one-third are under threat or not well enough known in the wild for a conservation category to be assigned.

Virtually all the Mexican species of conservation concern are globular species, easily transportable plants and ideal for greenhouse collections. The genus Mammillaria fits into this category. Conservative estimates place the number of Mexican species and subordinate taxa at 509 of which two-thirds are rare, threatened or insufficiently 148 known. More than 20 other collectable genera have species in decline. The larger columnar species belonging to the tribe Cereeae, the cactus 'trees', are not as threatened by collectors as they are in south-western states of the US, where plants are uprooted for garden landscaping. One of the Mexican cactus 'trees', Backebergia militaris, has not, however, escaped attention from trade. Plants of this monotypic genus, which grow to $6 \mathrm{~m}$ high, bear busby-like heads (cephalia). These are removed from mature plants, although the cuttings do not survive well in cultivation.

Pressure on Mexican cacti comes mainly from outside the country. Plants have been exported to Europe for over a century. The trade is now truly international despite the fact that Mexico has, in theory, banned the commercial export of all cacti taken from the wild since 1940. In addition, at the inception of The Convention on Trade in Endangered Species of Wild Fauna and Flora (CITES) in 1973 all cacti were placed on Appendix II, which means that international trade is only allowed under licence. Unfortunately, Mexico has not has yet ratified the Convention. The situation is not helped by the generally poor enforcement of CITES for plants by importing countries.

Since 1973 one genus and 34 species of cacti, representing some of the species most severely threatened by trade, have been upgraded to Appendix I of CITES, which forbids all international trade. Sixteen of these species, together with the genus Turbinicarpus, are Mexican endemics. The others are confined to the US or occur in both Mexico and the US. Wild-collected specimens of most of these plants have until recently been readily available from nurseries in

Oryx Vol 18 No 3 
Britain and elsewhere in Europe. At the National Cactus and Succulent Show held in Luton in August 1983, at least two nurseries were offering wild-collected Appendix I cacti. Following implementation of the EEC Regulations on CITES, which came into force in January 1984 , sale of wild-collected Appendix I plants is banned throughout the EEC.

Unfortunately, there is limited public support for cactus conservation. The thinking appears to be, as long as the wild plants are available for sale why stop buying them? The British Cactus and Succulent Society, like its Mexican and US counterparts, is officially conservation-minded as is the International Organisation for Succulent Plant Study, which produced a conservation code of conduct in 1974. The code encourages the propagation of rare species and discourages the purchase of wild-collected plants.

Cactus collecting has largely been to satisfy the horticultural and amateur scientific interest in the family. In the literature there are numerous examples of populations being avidly removed from the wild. Echinocereus davisii, a dwarf cactus of Brewster County, Texas was first described in 1931 with a very limited natural range. Following description, hundreds of specimens were removed by collectors and dealers, a process which continued until the land was acquired by owners who allowed no collecting. In the same area of Texas, other species of Echinocereus, together with plants of Mammillaria, Epithelantha, Echinocactus and Ariocarpus, are still being sold by the thousand with considerable wastage of plants left to rot after being uprooted.

An early misguided attempt at conservation led to the complete removal of a population of the very rare Mammillaria wrightii from the wild in New Mexico. The collector, after a concerted hunt in 1934, removed a stand of nearly 50 plants, which he believed represented the species in its entirety. All the plants were removed for the sake of species preservation, but there are no records of their survival in cultivation. Fortunately other populations have since been found in the wild.

Cultivation can play a major role in conservation only if propagation takes place. Echinocactus

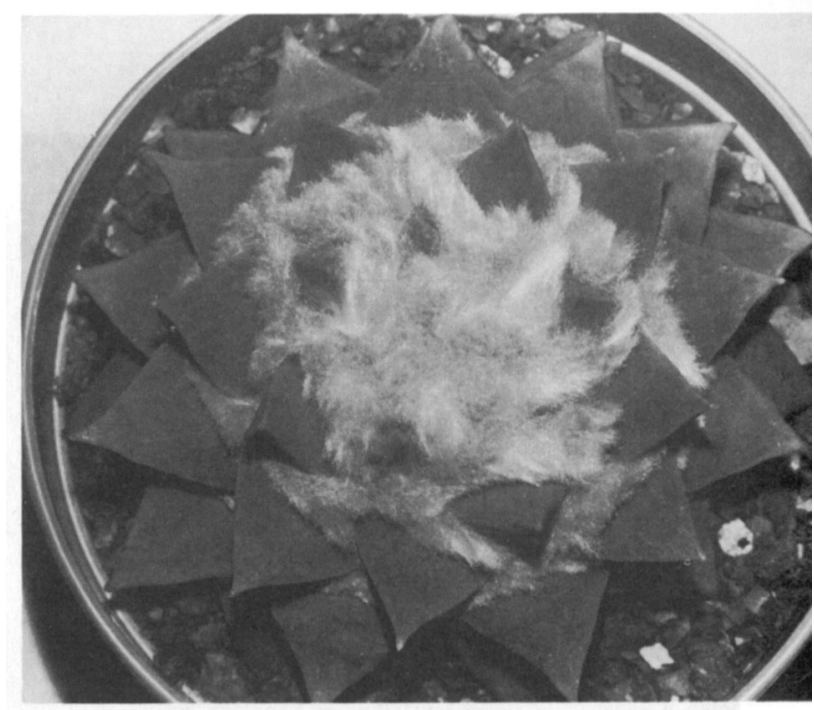

Ariocarpus retusus, one of a genus still being collected by the thousand from the wild in Texas (Mark Eban).

grusonii (golden barrel cactus), a Mexican species, is endangered in the wild. It is, however, grown on a vast scale in outdoor nurseries in California and the Canary Isles and is a common plant in collections. Tissue culture techniques are now being developed for cacti. There has been some success with rare plants such as Pediocactus, a genus of tiny US cacti which are difficult to grow from seed.

These methods help to reduce, albeit slowly, the pressure on wild populations. There is, however, only one cactus nursery in Mexico and this is unable to supply all the demands of collectors in the US, Europe and Japan. Japanese cactus hunters have in recent years strip-collected plants in parts of Mexico, including Cedros Island, off the coast of Baja California. Nurseries in Japan advertise in the specialist journals for Mexican cacti of threatened genera such as Ariocarpus and Pelecyphora.

There can be no substitute for cactus conservation in situ. In fragile desert ecosystems cacti form an important integral part of the environment. Selective collecting of species upsets the natural ecological balance. Some types of cacti are the dominant species within plant communities. This is the case with the giant cactus 'tree', the saguaro Camegiea gigantea, which occurs in the Sonora Desert of south-west US and the state' of Sonora in Mexico. Even this majestic 


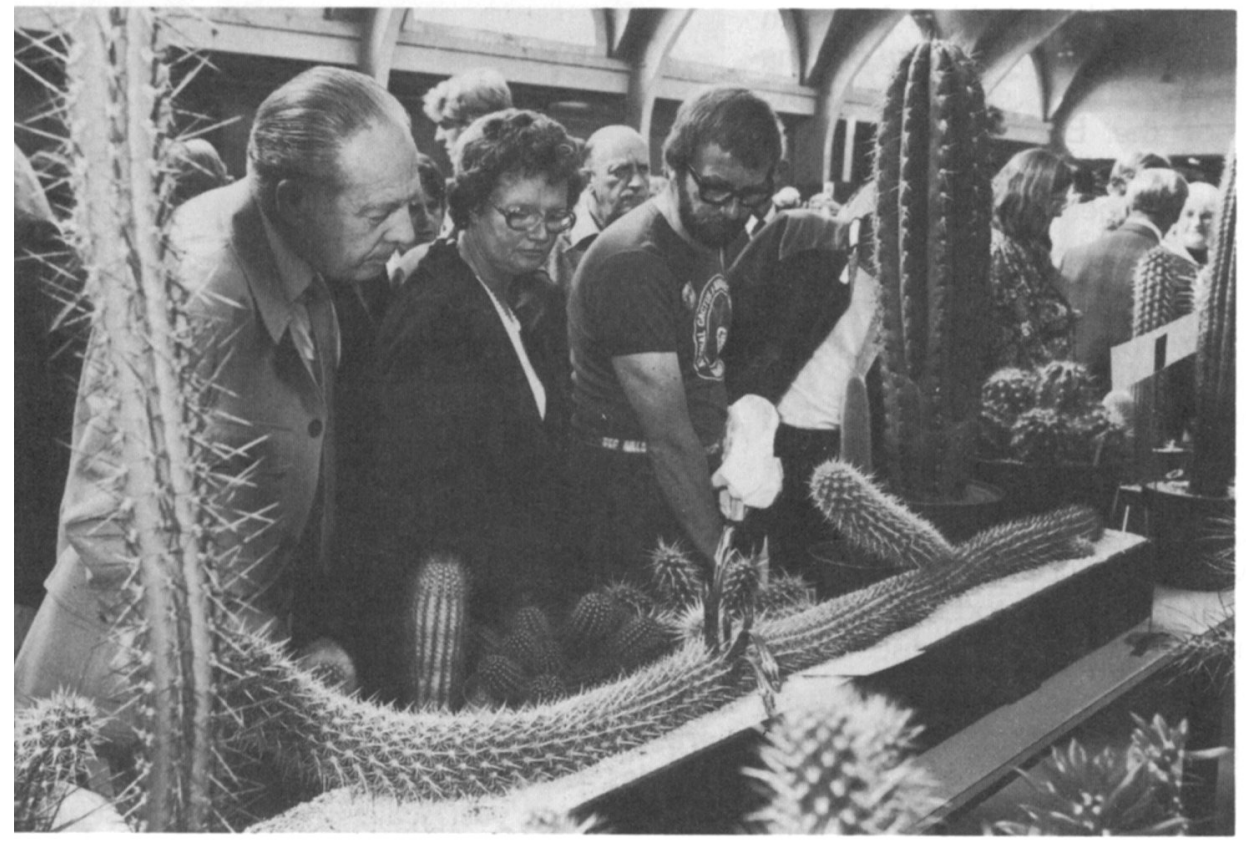

Creeping devil Stenocereus eruca, a rare endemic of the Magdalena Plain in Baja California, is threatened by irrigation schemes. Here it is pictured at a UK cactus show (Peter Chapman).

cactus is under threat, both from over-grazing and cactus rustlers. Urbanisation has reduced its range but the saguaro is fortunate in having a protected area set aside for it, the Saguaro National Monument in southern Arizona.

It might be expected that the harsh conditions tolerated by cacti would allow them a degree of protection from development. Irrigation schemes and consequent agricultural development, however, threaten the survival of plants in Baja California such as the extraordinary Stenocereus (Machaerocereus) eruca (creeping devil), a rare endemic of the Magdalena plain. In addition, urban spread, tourism, road building and mining take their toll of cacti in the all too familiar way.

Not all cacti are desert species. Species of the genus Pereskias, a genus of scarcely succulent xerophytic trees, are vulnerable to forest clearance in tropical America. Epiphytic species of genera such as Hylocereus, Epiphyllum and Rhipsalis are threatened in the same way. Rhipsalis is believed to be the only genus of cacti which has a natural distribution extending beyond the Americas. Two species are endemic to Madagascar and a further species occurs also in Africa and Ceylon.
The extent to which national protection is afforded to cacti varies considerably. Rare and threatened cacti in the US have, as would be expected, a higher degree of legal protection than cacti in any other country. Together with protection under various state laws, 21 species and varieties are listed as endangered or threatened under the federal Endangered Species Act. A further 69 taxa are under review. Listing ensures conservation efforts by the Fish and Wildlife Service with research, habitat acquisition and management, and ensures that federal agencies do not jeopardise the survival of the species. The legislation places strict controls on trade. In addition, since 1981 the Lacey Act in the US has prohibited export or interstate trade in wild plants collected in contravention of the law of the state of origin.

Recently a nursery owner was sentenced under the Lacey Act in the first conviction for trading in endangered cacti. More than 100,000 Mexican cacti had been illegally imported by Anthony Botanic Garden, using forged permits, for sale to private collectors. The company is known to have re-exported wild-collected Mexican Appendix I cacti to Britain.

Oryx Vol 18 No 3 
Field-collected specimens of Strombocactus disciformis, a Mexican endemic, classified as 'vulnerable' in the wild (Wilhelm Barthlott)

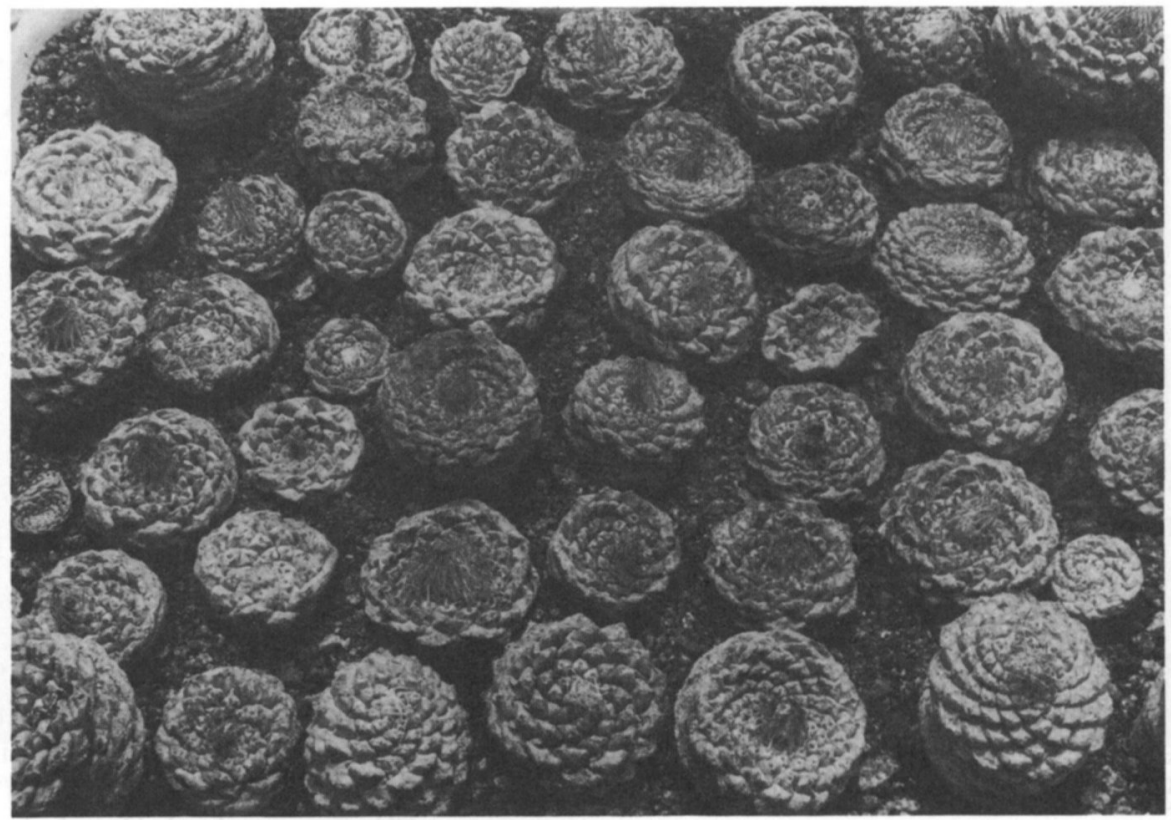

In South American countries basic taxonomic and biogeographical research are priorities for cactus conservation. The listing of the entire family Cactaceae on CITES has been criticised but it remains necessary as long as the wholesale removal from the wild of little known plants continues.

Over the past two decades South American cactus species have become increasingly popular in Europe. Thousands of imported plants arrived from Peru, Chile, Bolivia, Brazil and Argentina in the early 1970s, again mainly of the globular species. Most did not survive and in only a few cases propagation by seed or cuttings established species in cultivation. Tens of thousands of Discocactus plants are thought to have been lost over the last decade. Scientific study of this and similar genera is far from complete.

Very little is known of the conservation status of South America cacti. The five examples of threatened cacti chosen for the IUCN Plant Red Data Book (1978) are all species of Mexico or the USA, although the distribution of one of the species, Cephalocereus robinii, extends to Cuba.

The conservation status of Caribbean cacti has been assessed by the Threatened Plants Unit. Cactaceae, threatened by trade
Preliminary work revealed that out of 112 endemic taxa only 19 are known to be not threatened. Six Caribbean representatives of the attractive genus Melocactus are under threat, with two Cuban species classed as endangered. The first cacti to arrive in Europe were in fact Melocactus from the West Indies in the sixteenth century. Uprooted plants of this genus are notoriously difficult to establish in cultivation and no doubt repeated collection of the plants then known as 'Melonendistel' (melon-thistle) was necessary.

Importing countries have not as yet done enough to support cactus conservation. The trade is likely to place increasing strain on wild populations as long as the demand exists. Stricter enforcement of CITES remains necessary to show at the very least that conservation measures are being taken seriously for a plant family under threat from trade.

\section{Reference}

Lucas, G. and Synge, H. 1978. The IUCN Plant Red Dato Book. IUCN, Switzerland.

Sara Oldfield, Conservation Unit, Royal Botanic Gardens, Kew, Richmond, Surrey TW9 3AB, UK. 